\title{
Caloric needs of detritivorous gizzard shad Dorosoma cepedianum are met with sediment bacterial and algal biomass
}

\author{
J. C. Smoot ${ }^{1,2}$, R. H. Findlay ${ }^{1,3, *}$ \\ ${ }^{1}$ Department of Microbiology, Miami University, Oxford, Ohio 45056, USA \\ ${ }^{2}$ Present address: C/e $\mathrm{e}^{-}$Solutions, Inc., 925 San Tomas St., Davis, California 95618, USA \\ ${ }^{3}$ Present address: Department of Biological Sciences, University of Alabama, A-229 Bevil Building, Box 870206, \\ Tuscaloosa, Alabama 35487, USA
}

\begin{abstract}
The food source of sediment-ingesting animals is a subject of controversy, centering on the notion that the microbial biomass in sediments is insufficient to support caloric need. Gizzard shad Dorosoma cepedianum are omnivorous, sediment-ingesting fish that frequently impact the trophic structure of temperate lake and reservoir food webs. Prior gut content analyses of this fish have typically determined the bulk of ingested material to be amorphous matter. In the present study, lipid-based assays were used to quantify microbial biomass in sediment and to determine the food source undergoing digestion within the gut of gizzard shad. Microbial biomass was not uniformly distributed throughout the sediment; rather, the low-density fraction of sediment was enriched in microbial biomass nearly 7 -fold, compared to whole sediment. Gizzard shad ingesta contained 8 times more low-density sediment than whole sediment, suggesting selective feeding. On average, the ceca-lined segment of the gut contained $4.9 \mathrm{mg}$ dissolved lipid $\mathrm{ml}^{-1}$ gut fluid. Dissolved fatty acids were from bacteria and phototrophic microeukaryotes. Estimates of calories gained by the fish were in good agreement with a previous estimate of gizzard shad caloric requirements and indicated that bacteria and microeukaryotes were the food source of the fish. These findings indicate that (1) sediment microeukaryotes and bacteria serve as important food sources for gizzard shad, (2) selective feeding on a sediment fraction enriched in living microbial biomass meets fish caloric requirements, and (3) detritivory is the mechanism by which gizzard shad link benthic and pelagic food webs.
\end{abstract}

KEY WORDS: Detritivory $\cdot$ Gizzard shad $\cdot$ Bacteria $\cdot$ Algae $\cdot$ Benthic-pelagic coupling

\section{INTRODUCTION}

Most primary production, regardless of ecosystem, becomes detritus (Cebrian 2004, Cebrian \& Lartigue 2004), yet quantitative studies of detritus and detritivores within food webs, complex networks of energy and carbon transfers among groups of producers and consumers within and between ecosystems, are limited (Moore et al. 2004). Detritus in toto is a complex mixture of dead organic matter and the microorganisms that are either intimately or indiscriminately associated with the organic matter. However, much dead organic matter is recalcitrant or inaccessible to the digestive enzymes produced by detritivores, animals that consume and glean their nutritional requirements from detritus (Bowen 1979, 1984, Mayer et al. 1995). Microbes associated with detritus are a readily digestible food source, although their abundance is poorly understood because their small size makes quantifying their biomass technically challenging (Gough \& Stahl 2003, Boenigk 2004). Indeed, microbes are the unseen majority in the biosphere (Whitman et al. 1998), and accurate quantification of their biomass is essential in defining the microbes' roles in food webs. 
Gizzard shad Dorosoma cepedianum is an omnivorous detritivore that frequently impacts the status and structure of both higher and lower trophic food web levels (Stein et al. 1995, Vanni et al. 2005). Interestingly, gizzard shad influence food webs when their biomass is low or high. When gizzard shad biomass is low, they compete for zooplankton with fish larvae of higher trophic levels, they also rapidly grow beyond the capture size of predatory fish and act as nutrient pumps that stimulate primary productivity (Schaus et al. 1997, Garvey et al. 1998, Vanni 2002). However, gizzard shad biomass may reach several hundred kilograms per hectare in temperate freshwater ecosystems (Gu et al. 1996). Under these conditions, gizzard shad graze down zooplankton and switch to feeding on detritus. Detritivorous gizzard shad impact the benthos by disturbing invertebrate habitats and link aquatic food webs by returning nutrients from the benthic to the pelagic food web (Gido 2003, Nowlin et al. 2005, Higgins et al. 2006).

However, determining what food source is providing the energy and nutrients to detritivorous gizzard shad is problematic, since the bulk sediment alone does not possess adequate calories to sustain the fish (Pierce 1977), yet gizzard shad were successfully reared on a sediment diet in the laboratory, and the gut contents of wild fish commonly are filled with sediment regardless of lake nutrient trophic status (Weir \& Churchill 1945, Vanni et al. 2005). Measurements of gut content $\delta^{13} \mathrm{C}$ values suggest that sediment detritus is the main carbon source for gizzard shad, and analysis of their digestive fluids showed surfactant levels consistent with detritivory (Schaus et al. 2002, Smoot \& Findlay 2000). Gizzard shad gut contents are nutrient enriched compared to whole sediment; this may result from their ability to feed on particulate matter through a crossflow filtering mechanism (Sanderson et al. 2001).

We hypothesized that gizzard shad selectively feed on a low-density, detritus-rich fraction of sediment and digest the microbiota associated with the consumed detritus. To test these hypotheses, we partitioned sediment and ingesta into low- and high-density fractions ( $\rho \leq 1.9, \rho>1.9$, respectively; Mayer et al. 1993) and quantified the microbial community present in each fraction. To determine if fish were feeding selectively, we compared the percentage of low-density material in the sediment and ingesta. We used lipid biomarkers to measure the percentage of ingested biomass that was digested. Solid-phase polar lipid fatty acids were used as markers for living biomass (Vestal \& White 1989), and dissolved polar and neutral lipid fatty acids were used to indicate digestion of biomass. From dissolved lipids, we estimated the daily caloric ration available to fish from microbial biomass and the daily caloric content absorbed by the fish.

\section{MATERIALS AND METHODS}

Fish and sediment sampling. Gizzard shad Dorosoma cepedianum were collected August 1998, September 1998, and August 1999 from Acton Lake in southwestern Ohio, USA (described in Schaus et al. 1997). The 1998 experiments were designed to detect selective feeding (August and September samples), and to determine the food resource of gizzard shad and the calories gained through the digestion of living microbial biomass (September samples only). The 1999 experiment was designed to determine if ingested biomass in the esophagus and gizzard region $(E+G)$ was sufficient to account for the total lipid present in the cecal region. Gizzard shad were collected approximately $40 \mathrm{~m}$ north of a permanent buoy marking the Acton Lake 'River station' (Smoot \& Findlay 2001); this station is denoted as River station.

In 1998 fish were collected with a boat-mounted electroshocker (direct current, $120 \mathrm{~Hz}, 7 \mathrm{~A}$ ). Fish were immediately killed by cutting their cervical vertebrae, and their digestive tracts were removed. The entire digestive tract of each fish was clamped at the esophagus and anus, removed from the fish, double bagged, chilled in ice brine, and kept on wet ice until dissected in the laboratory. Removal of the digestive tract of one fish was completed prior to the capture of the next fish to minimize changes to digestive tract contents. Digestive tracts were dissected into 5 sections: the E+G region and 4 intestinal sections. The most anterior intestinal section was defined by the presence of the ceca (denoted CR); the remainder was sectioned into thirds and designated fore-intestine (FI), mid-intestine (MI), and hind-intestine (HI). Data from the MI and HI sections (MI-HI) were pooled based on measured surfactant and digestive enzyme activity of gut fluid (Smoot \& Findlay 2000). Regions were split lengthwise, and the contents were removed with a spatula, weighed, and centrifuged at $12000 \times g$ for $5 \mathrm{~min}$ at $4^{\circ} \mathrm{C}$. Gut fluid was removed with a micropipette (care was taken to include all gut fluid from the surface of the solids), and a subsample was lipid extracted. Solids from CR, FI, MI, and $\mathrm{HI}$ samples were transferred to $50 \mathrm{ml}$ glass test tubes, and lipid was extracted. The $1998 \mathrm{E}+\mathrm{G}$ samples were partitioned into low- and high-density fractions (see below) and weighed. There was 1 outlier in the data set (a September $1998 \mathrm{HI}$ sample), and it was removed from further analysis. Only data from the E+G samples for August 1998 fish are reported; all lipid extractions from August 1998 were lost.

In 1999, fish were collected early in the day with a cast net to optimize collecting ingesta from the $E+G$ of the fish. Gut contents were collected from E+G and CR using the same methods as in 1998. These samples underwent lipid analysis without density separation. 
Sediment samples were collected in August 1998 and August 1999 from the River station. Either 4 (1998) or 3 (1999) replicate cores were collected with $6.5 \mathrm{~cm}$ inner diameter corers, and intact cores were transported to the laboratory. Overlying water was removed without disturbing the sediment-water interface, and 5 surface sediment subsamples were collected with the barrels of $5 \mathrm{cc}$ syringes $\left(1.1 \mathrm{~cm}^{3}\right.$ of sediment per syringe). One subsample from each core was lipid extracted. The remaining 4 subsamples were pooled and partitioned into low- and high-density fractions. Pore water was removed from these samples using centrifugation as described above.

Density partitioning in $\mathrm{CsCl}$ solution. Fish ingesta (E+G gut contents; August and September 1998) and sediment samples were partitioned into low- and highdensity sediment fractions in a saturated cesium chloride $(\mathrm{CsCl})$ solution (particles with a density $\leq 1.9$ remained in suspension while particles with a density $>1.9$ formed a pellet; Mayer et al. 1993). Low- and high-density fractions were collected on $0.2 \mu \mathrm{m}$ Durapore filters (Millipore). These filters were rinsed with $45 \mathrm{ml}$ deionized water, dried $1 \mathrm{~h}$ at $100^{\circ} \mathrm{C}$, cooled under desiccation, and weighed prior to use. Sufficient ingesta for successful density separation was collected from 3 of 9 fish collected in 1998. These samples were processed individually, and the ingesta samples from the remaining 6 fish were pooled into 2 samples ( 3 fish per sample). After density fractionation of the samples, lipids were extracted, and the ingesta or sediment were recovered, dried, and weighed. Sample weights were corrected for the presence of salts by dissolving the samples in $1 \mathrm{ml}$ distilled water, measuring the solution's conductivity, and estimating the salt weight with a standard curve of salt weight vs. conductivity.

Lipid analyses. Total lipid from ingesta, gut fluid, gut solids, and sediment was extracted with $28.5 \mathrm{ml}$ dichloromethane (DCM)-methanol-phosphate buffer $(1: 2: 0.8$, v/v/v) (Findlay 2004). Lipid was either collected over a column containing anhydrous sodium sulfate (gut fluid, low-density ingesta, high-density ingesta, and low-density sediment samples) or over 2V-grade filter paper (whole sediment, high-density sediment, and gut solids). Total microbial biomass in the sediment was determined by measuring total phospholipid phosphate (Findlay 2004). Total lipid was split into polar- and neutral-lipid fractions with silica gel solid-phase extraction (SPE). Before use, silica was washed 3 times with DCM-methanol-deionized water $(5: 5: 1, v / v / v)$, dried under nitrogen, heated at $95^{\circ} \mathrm{C}$ for several hours, and stored under desiccation until used. Neutral lipids were collected in $5 \mathrm{ml}$ chloroform, and polar lipids were collected in $5 \mathrm{ml}$ DCM-methanolwater (5:5:1, v/v/v) after glycolipids were eluted in $5 \mathrm{ml}$ acetone (Findlay 2004). Polar lipid fatty acids were converted to fatty acid methyl esters (FAMEs) with mild alkaline methanolysis. FAMEs were purified using silica gel SPE (Findlay 2004). Neutral lipid fatty acids from gut fluid were converted to FAMEs with strong acid methanolysis (2 ml methanol-chloroform$12 \mathrm{~N} \mathrm{HCl}$ [9:1:1, v/v/v] for $1 \mathrm{~h}$ at $100^{\circ} \mathrm{C}$ ). After cooling to room temperature, FAMEs were collected in chloroform after partitioning against deionized water. FAMEs were identified using gas chromatographymass spectral analysis and quantified using gas chromatography with a flame ionization detector.

Calculations and statistical analyses. Bacterial and microeukaryotic biomass were calculated using phospholipid phosphate (PLP) to cellular carbon conversion factors of $100 \mu \mathrm{mol}$ PLP g ${ }^{-1}$ carbon for bacteria and $50 \mu \mathrm{mol}$ PLP $\mathrm{g}^{-1}$ carbon for microeukaryotes (Dobbs \& Findlay 1993). The quantity of phospholipid from microeukaryotes was determined from the molar concentration (nmol g ${ }^{-1}$ dry wt) of polyenoic FAMEs, assuming an average molecular weight of 298 and that $50 \%(\mathrm{~mol} / \mathrm{mol})$ of microeukaryotic membrane fatty acids are polyenoic (Findlay \& Dobbs 1993). Bacterial biomass was determined by difference. ANOVA and Tukey-Kramer post hoc pair-wise comparisons $(\alpha=0.05)$ were done using MiniTab12. Proportional data were natural log transformed before ANOVA.

Prior to statistical analysis for treatment effects, the density profile of August and September 1998 ingesta samples were compared by 1-way ANOVA using sampling date as the treatment. Similarly, densitypartitioned sediment samples were also tested for sampling date bias. These analyses indicated that grouping dates within treatments did not introduce a sampling date bias for either ingesta or sediment samples ( $p>0.90$, ingesta; $p=0.10$, sediment). A 1 -way ANOVA using percent low-density material in ingesta and sediment as treatments was used to test whether gizzard shad feed selectively.

Caloric contributions from living biomass were estimated using 3 models for each fish sampled in September 1998. Two models of gizzard shad digestion were based on plug-flow reactor models and optimal digestion theory (Penry \& Jumars 1987) and used gut lipid concentrations. The third model estimated caloric assimilation based on a previously determined ratio of calories to ash-free dry mass. Throughput $(\mathrm{T})$, the time required for passage of 1 gut volume, was based on an estimated fish intestine volume and on passage rates from a previous study (Salvatore et al. 1987) as modified by Mundahl (1991) to account for temperature $\left(76.998 \times\right.$ temperature $\left.^{-0.977}\right)$ and further modified by Vanni \& Headworth (2004) to account for fish size: $\left(76.998 \times\right.$ temperature $\left.^{-0.977}\right) \times\left(0.6 \times\right.$ wet $\left.\mathrm{wt}^{0.285}\right)$. For the present study, $25^{\circ} \mathrm{C}$ water temperature was used, and 
fish standard lengths were converted to wet weights such that:

$\ln ($ wet wt $)=3.0705 \times \ln ($ standard length $)-11.399$

This equation was derived from regression analysis of fish that were previously collected, weighed, and measured $\left(\mathrm{R}^{2}=0.9473, \mathrm{n}=33\right)$.

Gut volumes were estimated using the standard volumetric equation for a cylinder. Gut section lengths were approximately $4 \mathrm{~cm}$ for the $\mathrm{CR}$ and $7 \mathrm{~cm}$ for the remaining gut sections. In preliminary work, fish intestine length to fish standard length ratios (I:L) indicated that gizzard shad (63 to $212 \mathrm{~mm}$ standard length, $\mathrm{n}=14$ ) had an average $\mathrm{I}: \mathrm{L}$ of 2.4 , but this ratio was variable $(\mathrm{CV}=22 \%)$. An estimate of total intestine length $(25 \mathrm{~cm})$ for the $110 \mathrm{~mm}$ standard length fish was used in the present study based on preliminary data and previously published I:L ratios (Mundahl 1984). The intestine tapers posterior to the FI, and, to compensate for the reduced volume, sections were treated as individual cylinders. Intestinal radii were estimated at $0.25 \mathrm{~cm}$ (CR and FI), $0.20 \mathrm{~cm}(\mathrm{MI})$, and $0.125 \mathrm{~cm}(\mathrm{HI})$.

The calories SOLUBiLIzed $_{\text {model required }}$ assigning all fatty acids to either a microeukaryotic or bacterial origin, because the conversions from lipid to calories are different for these 2 groups due to differences in their macromolecule composition (Table 1). This assignment also allowed an estimation of the importance of bacteria and microeukaryotes to gizzard shad nutrition. Daily caloric contributions to the fish from digested cellular macromolecules were based on dissolved lipid concentrations in the $\mathrm{CR}$ and were calculated as:

Calories $_{\text {SolUBilized }}=\left(\mathrm{Cal}_{\text {EUK-S }}+\mathrm{Cal}_{\mathrm{BAC}-\mathrm{S}}\right) \times \mathrm{P}_{\mathrm{CR}}$

where $\mathrm{Cal}_{\mathrm{EUK}-\mathrm{S}}$ and $\mathrm{Cal}_{\mathrm{BAC}-\mathrm{S}}$ are the calories contributed by microeukaryotes and bacteria, respectively, and $\mathrm{P}_{C R}$ is the number of passages through the CR per day. The calories contributed by microeukaryotes and bacteria were calculated with Eq. (3) and Eq. (4), respectively:

$$
\begin{aligned}
& \mathrm{Cal}_{\mathrm{EUK}-\mathrm{s}}= \Sigma\left(\mathrm{L}_{\mathrm{CR}} \times \mathrm{V}_{\mathrm{CR}} \times \%_{\mathrm{EUK}} \times \mathrm{Cal}_{\mathrm{i}} \times \mathrm{Z}_{\mathrm{i}} / \mathrm{Z}_{\mathrm{L}}\right), \\
& \text { for } \mathrm{i}=1 \text { to } 4 \\
& \mathrm{Cal}_{\mathrm{BAC}-\mathrm{s}}=\Sigma\left(\mathrm{L}_{\mathrm{CR}} \times \mathrm{V}_{\mathrm{CR}} \times \%_{\mathrm{BAC}} \times \mathrm{Cal}_{\mathrm{i}} \times \mathrm{Z}_{\mathrm{i}} / \mathrm{Z}_{\mathrm{L}}\right), \\
& \text { for } \mathrm{i}=1 \text { to } 4
\end{aligned}
$$

where $L_{C R}$ is the concentration of dissolved neutral and polar lipid $\left(\mathrm{mg} \mathrm{ml}^{-1}\right)$ in the lumen of the $C R, V_{C R}$ is the volume of the $C R, \%_{\mathrm{EUK}}$ and $\%_{\mathrm{BAC}}$ are the percentages (as a decimal fraction) that eukaryotic and bacterial lipid, respectively, comprised of total dissolved lipid, $\mathrm{Cal}_{\mathrm{i}}$ is the calories per milligram by macromolecule class, $Z_{i}$ is the percentage cellular composition by macromolecule class, $\mathrm{Z}_{\mathrm{L}}$ is the percentage cellular lipid, and 1,2, 3 and 4 represent the 4 major macromolecule classes comprising cells (Table 1). $P_{C R}$ was calculated as:

$$
\mathrm{P}_{\mathrm{CR}}=(\mathrm{v} \times \mathrm{H}) / \mathrm{V}_{\mathrm{CR}}
$$

where $\mathrm{v}$ is the gut flow $\left(\mathrm{ml} \mathrm{h}^{-1}\right)$ and $\mathrm{H}$ is the feeding duration $\left(\mathrm{h} \mathrm{d}^{-1}\right)$ (Table 2$)$.

In the calories ${ }_{A B S O R B E D}$ model, daily caloric contributions to the fish from digested cellular macromolecules were based on the difference between dissolved lipid concentrations in the $\mathrm{CR}$ and $\mathrm{HI}$ and were calculated as:

$$
\text { Calories }_{\mathrm{ABSORBED}}=\left(\mathrm{Cal}_{\mathrm{EUK}-\mathrm{AB}}+\mathrm{Cal}_{\mathrm{BAC}-\mathrm{AB}}\right) \times \mathrm{P}_{\mathrm{CR}-\mathrm{MI}}
$$

\begin{tabular}{|c|c|c|}
\hline Parameter & Value & Source \\
\hline Throughput (T) & $5.2 \mathrm{~h}$ & $\begin{array}{l}\text { Salvatore et al. (1987), } \\
\text { Mundahl (1991), Vanni \& } \\
\text { Headworth (2004) }\end{array}$ \\
\hline Feeding duration $(\mathrm{H})$ & $13.0 \mathrm{~h} \mathrm{~d}^{-1}$ & Pierce et al. (1981) \\
\hline Total gut volume (V) & $3.4 \mathrm{ml}$ & Present study \\
\hline Cecal region volume $\left(\mathrm{V}_{\mathrm{CR}}\right)$ & $0.79 \mathrm{ml}$ & Present study \\
\hline Hind Intestine volume $\left(\mathrm{V}_{\mathrm{HI}}\right)$ & $0.34 \mathrm{ml}$ & Present study \\
\hline Gut flow (v) & $0.65 \mathrm{ml} \mathrm{h}^{-1}$ & $\begin{array}{l}\text { Salvatore et al. (1987), } \\
\text { Mundahl (1991), Vanni \& } \\
\text { Headworth (2004), } \\
\text { present study }\end{array}$ \\
\hline $\begin{array}{l}\text { Caloric content of } \\
\text { ingesta }\left(\mathrm{Cal}_{\text {INGESTA }}\right)\end{array}$ & $\begin{array}{l}3150.0 \mathrm{cal} \mathrm{g}^{-1} \\
\text { AFDM }\end{array}$ & Pierce (1977) \\
\hline $\begin{array}{l}\text { Organic content of ingesta } \\
\left(\%_{\text {ORG }}\right)\end{array}$ & $17.9 \%$ & Pierce (1977) \\
\hline Assimilation efficiency (E) & $42.0 \%$ & Pierce (1977) \\
\hline Density of gut solids $(\rho)$ & $2.0 \mathrm{~g} \mathrm{ml}^{-1}$ & Assumed \\
\hline $\begin{array}{l}\text { Solid content of ingesta } \\
\left(\%_{\mathrm{SOL}}\right)\end{array}$ & $28.0 \%$ & Present study \\
\hline
\end{tabular}

Table 1. Cellular composition and caloric values used in solubilization and absorption models. Class: as used in Eqs. (3), (4), (7) \& (8)

\begin{tabular}{|lcccc|}
\hline Macromolecule & Class & $\begin{array}{c}\text { Cellular composition (\%) } \\
\text { Bacteria }^{\text {a }}\end{array}$ & $\begin{array}{c}\text { Algaloric values }^{\text {b }} \\
\text { (cal mg }^{-1} \text { ) }\end{array}$ \\
\hline Lipid & 1 & 9 & 12 & 9 \\
Protein & 2 & 55 & 48 & 4 \\
Carbohydrate & 3 & 6 & 24 & 4 \\
Nucleic acid & 4 & 24 & 25 & 4 \\
aNeidhardt et al. (1990) & & & \\
bolesky et al. (1969) & & & \\
\end{tabular}

Table 2. Parameters used to model the role of microbes as a food source for gizzard shad Dorosoma cepedianum. AFDM: ash-free dry mass 
where $\mathrm{Cal}_{\mathrm{EUK}-\mathrm{AB}}$ and $\mathrm{Cal}_{\mathrm{BAC}-\mathrm{AB}}$ are the calories contributed by microeukaryotes and bacteria, respectively, and $\mathrm{P}_{\mathrm{CR}-\mathrm{MI}}$ is the number of passages through the CR, FI, and MI per day (Table 1). The calories contributed by microeukaryotes and bacteria were calculated with Eq. (7) and Eq. (8), respectively:

$$
\begin{aligned}
& \mathrm{Cal}_{\mathrm{EUK}-\mathrm{AB}}=\Sigma\left\{\left[\left(\mathrm{L}_{\mathrm{CR}} \times \mathrm{V}_{\mathrm{CR}-\mathrm{MI}}\right)-\left(\mathrm{L}_{\mathrm{HI}} \times \mathrm{V}_{\mathrm{CR}-\mathrm{MI}}\right)\right] \times\right. \\
& \left.\%_{\text {EUK }} \times \mathrm{Cal}_{\mathrm{i}} \times \mathrm{Z}_{\mathrm{i}} / \mathrm{Z}_{\mathrm{L}}\right\} \text {, for } \mathrm{i}=1 \text { to } 4 \\
& \mathrm{Cal}_{\mathrm{BAC}-\mathrm{AB}}=\Sigma\left\{\left[\left(\mathrm{L}_{\mathrm{CR}} \times \mathrm{V}_{\mathrm{CR}-\mathrm{MI}}\right)-\left(\mathrm{L}_{\mathrm{HI}} \times \mathrm{V}_{\mathrm{CR}-\mathrm{MI}}\right)\right] \times\right. \\
& \left.\%_{\mathrm{BAC}} \times \mathrm{Cal}_{\mathrm{i}} \times \mathrm{Z}_{\mathrm{i}} / \mathrm{Z}_{\mathrm{L}}\right\} \text {, for } \mathrm{i}=1 \text { to } 4
\end{aligned}
$$

where $\mathrm{L}_{\mathrm{HI}}$ is the concentration of dissolved neutral and polar lipid $\left(\mathrm{mg} \mathrm{ml}^{-1}\right)$ in the lumen of the HI region, $\mathrm{V}_{\mathrm{CR}-\mathrm{MI}}$ is the volume of the $\mathrm{CR}, \mathrm{FI}$, and $\mathrm{MI}(\mathrm{ml})$, and $\mathrm{P}_{\mathrm{CR}-\mathrm{MI}}$ was calculated as:

$$
\mathrm{P}_{\mathrm{CR}-\mathrm{MI}}=(\mathrm{v} \times \mathrm{H}) / \mathrm{V}_{\mathrm{CR}-\mathrm{M}}
$$

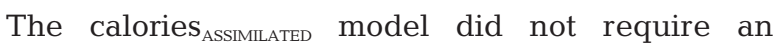
assumption of equal digestion efficiency of macromolecules and was based on our measurements of total gut volume $(\mathrm{V})$, volume of gut contents, and percentage of solids in gut contents $\left(\%_{\mathrm{SO}}\right)$. This model required an assumption of the density of gut solids $(\rho)$, which was used to convert from volume of gut solids (measurement used in the present study) to weight of gut solids (as used by Pierce 1977). We used Pierce's (1977) measurements of caloric content of ingesta ( $\mathrm{Cal}_{\text {INGESTA; }} \mathrm{cal} \mathrm{g}^{-1}$ ash-free dry mass $[\mathrm{AFDM}])$, organic content of ingesta $\left(\%_{\mathrm{ORG}}\right)$, and assimilation efficiency (E) (Table 2). Calories assimilated were calculated as:

$$
\text { Calories }_{\text {ASSIMILATED }}=\operatorname{cal}_{\text {INGESTA }} \times \mathrm{AFDM}_{\text {ING }} \times \mathrm{E}
$$

where $\mathrm{AFDM}_{\mathrm{ING}}$ is grams AFDM ingested per day and was calculated as:

$$
\mathrm{AFDM}_{\mathrm{ING}}=\mathrm{v} \times \mathrm{H} \times \%_{\mathrm{SOL}} \times \rho \times \%_{\mathrm{ORG}}
$$

The 3 resulting estimates of calories gained were compared by 1-way ANOVA.

\section{RESULTS}

The hypothesis that gizzard shad Dorosoma cepedianum selectively consume low-density sediment was tested by comparing the density profile of ingesta and sediments. Ingesta contained, on average, 8 times more low-density material than sediments (ANOVA, $\mathrm{p}<0.005 ; F=33.71, \mathrm{n}=5$, ingesta; $\mathrm{n}=16$, sediment), although the percentage of the low-density material in ingesta was quite variable compared to in the sediment ( 0.8 to $15 \%$ vs. 0.6 to $0.8 \%$ ).

The gut contents of gizzard shad from Acton Lake in the present study were 'green with a gritty, sand-like consistency', as has previously been described (Mundahl 1984). Contents of the CR of the intestine were fluid, whereas the contents of the HI were compact feces. The intestines of all fish collected in 1998 were full from the CR to the anus. Total intestinal lipid content ranged from 2.2 to $4.0 \mathrm{mg} \mathrm{ml}^{-1}$ gut volume and did not significantly differ among gut sections $(\mathrm{p}>$ 0.22; Fig. 1a). However, dissolved lipid decreased significantly down the gut, with lipid concentrations of 4.9 and $1.5 \mathrm{mg} \mathrm{ml}^{-1}$ gut fluid in the CR and MI-HI regions, respectively (Fig. 1b). The lack of an overall change in total gut lipid is explained by a substantial increase in solid-phase phospholipid (Fig. 1c) and a shift in the proportion that dissolved and solid-phase lipids contributed to total lipids (Fig. 1d). The increase in solidphase phospholipid (membrane component of living biomass) down the gut indicated the growth of microorganisms in the MI-HI region and/or an accumulation of sloughed, intact epithelial cells. Fatty acid profiles of solid-phase phospholipid indicated growth of bacteria.

The caloric contribution of consumed microbial biomass was estimated using 3 models (Table 3 ). The caloric contributions to fish daily diet were 1270 and $1080 \mathrm{cal} \mathrm{fish}^{-1} \mathrm{~d}^{-1}$ with the calories SOLUBiLzed $_{\text {and calo- }}$ ries $_{\text {ABSORBED }}$ models, respectively. These 2 estimates were not statistically different $(F=0.17, \mathrm{p}=0.69)$, and their agreement supported the assumption of dissolution being the rate-limiting step of digestion. In these 2 models, microeukaryotic (mostly originating from algae) and bacterial biomass were distinguished by using polyenoic fatty acids as biomarkers for microeukaryotes (Vestal \& White 1989). Microeukaryotes and bacteria each provided approximately $50 \%$ of the total calories digested. The calories ASSIMILATED model indicated that gizzard shad assimilated $1120 \mathrm{cal} \mathrm{fish}^{-1} \mathrm{~d}^{-1}$ (Table 2). This calculation, which did not require the assumption that microbial macromolecules were dissolved with equal efficiency, was in agreement with the estimates from the calories SOLUBILIZED and calories ${ }_{\text {ABSORBED }}$ models.

In 1999, the microbial biomass of ingesta collected from the $E+G$ was 7 times greater than the microbial biomass of River sediment (Fig. 2). In addition, the microbial biomass of ingesta from the $E+G$, ingesta from the $C R$, and the low-density fraction of the sediment were similar and significantly greater than the biomass of whole and high-density sediments (Fig. 2). The total lipid concentration of ingesta from the $\mathrm{E}+\mathrm{G}$ was $5.0 \pm 2.6 \mathrm{mg} \mathrm{ml}^{-1}$, while the total lipid concentration in the CR was $1.4 \pm 1.0 \mathrm{mg} \mathrm{ml}^{-1}$. These results confirm the 1998 observations that gizzard shad selectively feed on the low-density portion of the sediments in an effort to consume the biomass-rich portion of the sediments. 

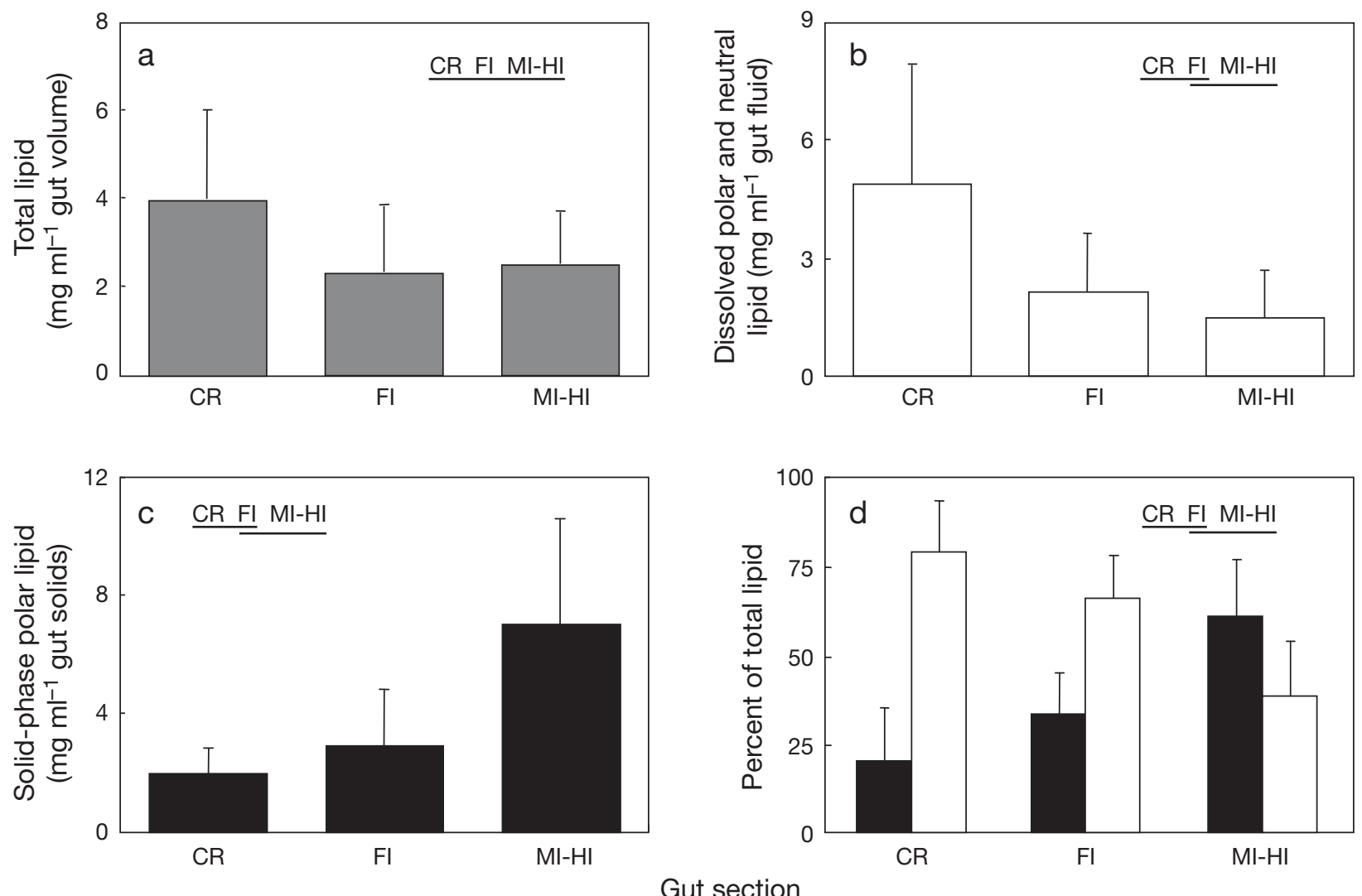

Fig. 1. Dorosoma cepedianum. Lipid content of gizzard shad intestines by section. CR: cecal region; FI: fore-intestine; MI: midintestine; HI: hind-intestine. MI and HI data were grouped based on the findings of Smoot \& Findlay (2000). Fish were collected from the River station during September 1998. (a) Total lipid calculated as the sum of gut solids (phospholipids) and gut fluids (neutral and polar lipids), (b) neutral and polar lipids dissolved in gut fluid, (c) phospholipids recovered from gut solids, (d) percentage that dissolved lipids (open bars) and solid-phase lipids (black bars) comprise of total lipid. Bars and error bars indicate means $+1 \mathrm{SD} ; \mathrm{n}=5$ for CR, $\mathrm{n}=4$ for FI, and $\mathrm{n}=6$ for MI-HI. Inserts show the results of ANOVA followed by Tukey-Kramer post hoc pair-wise comparisons; sample abbreviations not connected by a horizontal line are significantly different at $\mathrm{p}=0.05$

Table 3. Estimates of daily calories gained by gizzard shad Dorosoma cepedianum from living biomass and ash-free dry mass (AFDM). Values in parentheses $=1 \mathrm{SD}, \mathrm{n}=5$

\begin{tabular}{|c|c|}
\hline $\begin{array}{l}\text { Model } \\
\text { Parameter }\end{array}$ & Value \\
\hline \multicolumn{2}{|l|}{ Calories $_{\text {SOLUBLIZED }}$} \\
\hline Passages $\left(\mathrm{d}^{-1}\right)$ & 10.8 \\
\hline Calories from eukaryotic biomass & $63.1(40.7)$ \\
\hline Calories from prokaryotic biomass & $52.2(30.9)$ \\
\hline Calories $_{\text {SolubuzEd }}\left(\mathrm{d}^{-1}\right)$ & $1270(780)$ \\
\hline \multicolumn{2}{|l|}{ Calories $_{\mathrm{ABSORBED}}$} \\
\hline Passages $\left(\mathrm{d}^{-1}\right)$ & 2.9 \\
\hline Lipid absorbed per passage & $8.3(4.8)$ \\
\hline Calories absorbed per passage & $362.1(207.5)$ \\
\hline Calories $_{\text {ABSORBED }}\left(\mathrm{d}^{-1}\right)$ & $1080(540)$ \\
\hline \multicolumn{2}{|l|}{ Calories $_{\text {ASSIMILATED }}$} \\
\hline AFDM ingested $\left(\mathrm{d}^{-1}\right)$ & 0.85 \\
\hline Calories $_{\text {ASSIMILATED }}\left(\mathrm{d}^{-1}\right)$ & 1120 \\
\hline
\end{tabular}

\section{DISCUSSION}

Direct measurement of ingested material showed that low-density sediment and solid-phase phospholipid (indicative of living biomass) were concentrated in the E + G of gizzard shad Dorosoma cepedianum and suggests that living microbial biomass is an important food source for sediment-ingesting gizzard shad. Moreover, the high concentration of soluble lipid in the $\mathrm{CR}$, the significant decrease in soluble lipid concentration down the gut, and the presence of marker fatty acids for both bacteria and microeukaryotes within the dissolved lipid demonstrated that sediment microbial biomass is utilized as a food source by gizzard shad. The production of soluble neutral lipid originating as partially or fully hydrolyzed digestion products of microbial biomass within the CR was additional evidence that gizzard shad used the living component of detritus as a food source. Our previous demonstrations that the CR was the point of maximum surfactant and 


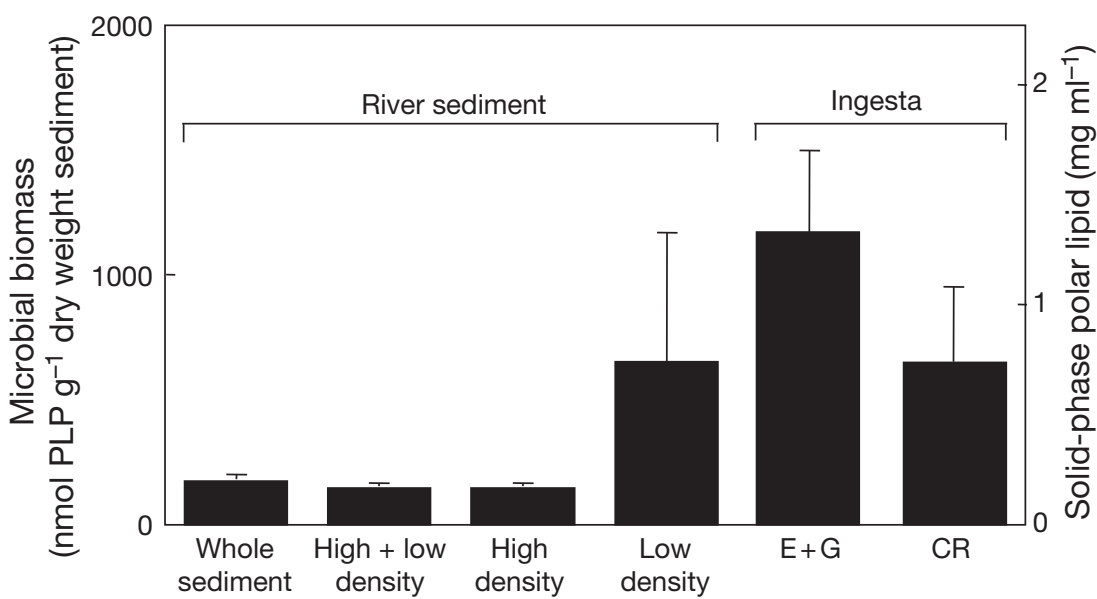

Fig. 2. Dorosoma cepedianum. Comparison of total microbial biomass, measured as phospholipid phosphate (PLP) of sediment, sediment fractions, and ingesta collected from the esophagus + gizzard $(E+G)$ and cecal region $(\mathrm{CR})$ of the intestine. Fish and sediment were collected from the River station during August 1999. Bars and error bars indicate mean + 1 SD microbial biomass from whole sediment, high-density sediment, and low-density sediment $(\mathrm{n}=3)$, microbial biomass of ingesta collected from the $E+G(n=5)$, and microbial biomass of ingesta collected from the CR $(\mathrm{n}=4)$. The bar labeled high + low density represents an estimate of total sediment microbial biomass obtained by mathematically combining the measured sediment microbial biomass from the low- and high-density sediment fractions

digestive enzyme activity provide mechanistic confirmation of the observed trends (Smoot \& Findlay 2000). Testing if gizzard shad possess nutrient transporters with $K_{\mathrm{m}}$ values (affinity for substrates) in the micromolar range, as reported for other animal digestive systems, would further elucidate gizzard shad physiologic adaptations to detritivory (Diamond 1991, Mayer et al. 1997); however, analysis of gizzard shad nutrient transporter kinetics was beyond the scope of the present study. Regardless, the concentrations of dissolved lipid were comparable to glucose and amino acid concentrations measured in vertebrate guts and amino acid concentrations measured in the gut fluids of carnivorous marine invertebrates (Diamond 1991, Mayer et al. 1997) and indicate that lipids dissolved in gizzard shad gut fluids are at sufficient concentrations to facilitate transport.

An alternative interpretation of the large amounts of dissolved lipid in the $\mathrm{CR}$ is that lipids were being secreted into the CR gut lumen by the fish. Lipid in CR gut fluid was dominated by neutral lipid with polar-toneutral lipid fatty acid ratios ranging from 0.1 to 0.3 , which are indicative of digestion. In comparison, polarto-neutral lipid fatty acid ratios were 1.0 and 3.4 in River station sediments and in the high-density fraction of fish ingesta, respectively. These are similar to previously observed ratios for sediments (Findlay et al. 1990, White et al. 1997). Unfortunately, insufficient material was collected from the E+G in 1998 to allow a comparison of lipid content of the ingesta in the $\mathrm{E}+\mathrm{G}$ to total lipid in the CR. Fish were collected in 1999 to provide this mass balance. While the lipid content of the $\mathrm{E}+\mathrm{G}$ exceeds that of the CR, 1999 sampling was conducted early in the morning to maximize the probability of recovering ingested material from the $E+G$, and the CR may not have yet filled. However, the total lipid in the $E+G$ is comparable to the total lipid observed in the CR during the 1998 sampling and is sufficient to accept the hypothesis that dissolved lipids present in the CR (for both the 1998 and 1999 samplings) originated from lipids in food and not as fish digestive secretions.

Optimal digestion-theory-based models apply chemical reactor theory to digestion (Penry \& Jumars 1986). The digestive tract was modeled as a continuous plug-flow reactor (PFR) because posterior to the gizzard is an intestine lined with hundreds of blind end sacs (ceca) that cluster and empty at several points into one side of the intestine followed by a long tapered tube folded several times so as to fit within the body cavity of the fish. Under PFR conditions, the model predicts that optimal digestion occurs at the balance between optimal enzyme-to-substrate concentration and foraging rate. Inefficient digestion occurs if the throughput rate is too fast or too slow for a given gut volume (Penry \& Jumars 1986). Therefore, 2 features of digestive physiology that are important model variables are gut volume and throughput rate (the rate of passage through a given volume). These variables are dependent on biotic and abiotic determinants such as reproductive cycles and season; in the present study, the number of passages through the CR and through the entire intestine were estimated for the time of year that the fish were sampled. The agreement of the 2 lipid-based estimates of calories gained through digestion along with an estimate made using previously determined sediment AFDM (Pierce et al. 1980) support the hypothesis that microbial biomass is the food source of detritivorous gizzard shad. Furthermore, the average energy of respiration calculated from oxygen consumption by 19.0 to $25.7 \mathrm{~g}$ gizzard shad (the approximate size of fish in this study) at temperatures similar to those in the present study $\left(1004 \pm 291 \mathrm{cal} \mathrm{fish}^{-1} \mathrm{~d}^{-1}\right.$; Pierce 1977) agrees with the estimates of calories gained through digestion.

Benthic microbes, bacteria, and sediment microeukaryotes (both benthic microeukaryotes and re- 
cently deposited algae from the overlying water column), support the nutrition of detritivorous gizzard shad (Smoot \& Findlay 2010), and indigestible detritus and sediment mineral grains are ingested to gain access to these food sources. This is similar to the widely cited 'peanut butter and nutritional unsuitable crackers' analogy used to describe the processing of leaf litter by shredder aquatic insects in streams (Cummins 1974) and is in general agreement with an estimate of utilization of bacterial carbon (40\%) by aquatic insects in first-order streams (Hall \& Meyer 1998). Other studies, mainly marine and based on direct counts of bacteria, have suggested that living bacterial biomass could provide no more than a few percent of the total carbon requirements of these animals (Bowen et al. 1984, Lopez \& Levinton 1987, Cammen 1991). However, Findlay et al. (1989) showed that direct counts underestimated total microbial abundance in marine sediments by 2.7- to 31-fold, depending on sediment type. A recent marine study, using ${ }^{13} \mathrm{C}$-labeled glucose, concluded that bacteria provide between 8 and $11 \%$ of the carbon requirements of animals feeding on sediment (van Oevelen et al. 2006). The source of the discrepancy between these findings is unclear. It may originate in the fundamental difference between detrital food webs in marine and freshwater sediments or may simply result from the choice of methods used to determine food resources (phospholipid analysis vs. direct counts and ${ }^{13} \mathrm{C}$-labeled acetate [Hall \& Meyer 1998] vs. ${ }^{13} \mathrm{C}$-labeled glucose [van Oevelen et al. 2006]). The latter may be of particular importance in light of the differences in glucose and acetate utilization kinetics (Wright \& Hobbie 1966). This discrepancy will likely remain unresolved until studies using comparable methods are conducted in both habitats.

The total microbial biomass in the present study was similar to the biomass previously measured at the River station (Smoot \& Findlay 2001) and in other freshwater and marine surface sediments (e.g. Dobbs \& Findlay 1993), indicating that microbial biomass, in quantities sufficient to support the caloric requirements of sediment-consuming detritivorous animals, is widely distributed throughout benthic sediments. These findings challenge the long-held, and still suggested (e.g. Bowen et al. 2006), notion that living microorganisms are insufficient in biomass to support the caloric requirements of detritivorous animals. Acceptance of the hypothesis that living bacterial and microeukaryotic biomass is the food resource of sediment-ingesting detritivores allows integration of animal natural history with ecosystem ecology. For instance, the observations that microeukaryotic and bacterial biomass is decreased in sediments after feeding by marine invertebrates (Findlay \& White 1983, Dobbs \& Guckert 1988, Findlay et al. 1990), marine invertebrates and fish can be successfully reared on bacterial diets (MacGinitie 1932), and vertebrates and invertebrates have anatomic and physiologic mechanisms for algal and bacterial cell lysis (Moriarty 1973, Plante \& Mayer 1994) become a consistent suite of observations indicating the importance of sediment microorganisms within benthic food webs. Furthermore, fish feeding on living microbial biomass is consistent with sedimentingesting detritivores possessing digestive enzymatic capacities that are comparable to carnivores and nonruminant herbivores (Mayer et al. 1997) and eliminates the requirement that detritivores possess extraordinary digestive capacity or that microorganisms altruistically or inadvertently 'condition' detritus prior to detritivore ingestion. Thus, recalcitrant dead organic matter is transformed into readily digestible molecules through the growth of decomposers, and this secondary production results in living tissue capable of meeting the caloric needs of detritivores. Detritivores, as a food resource for predators, link grazer and decomposer pathways within food webs (Hairston \& Hairston 1993, Moore et al. 2004), as well as connecting benthic and pelagic food webs in aquatic ecosystems (Vadeboncoeur et al. 2002, Vander Zanden \& Vadeboncoeur 2002). The importance of bacteria as a food resource also provides a mechanistic understanding of how allochthonous detritus from surrounding watersheds, which should be metabolically unavailable given the digestive capacity of gizzard shad and other detritivores (Mayer et al. 1997, Smoot \& Findlay 2000), provides subsidies within aquatic ecosystems (Pace et al. 2004, Kim et al. 2007). These insights are critical in systematically modeling ecosystems and producing stoichiometric mass balances of carbon flow through the various threads of ecosystem food webs.

Acknowledgements. We thank L. Schick and L. Mayer, Darling Marine Center, University of Maine, for their technical assistance with density separation procedures; and J. Brannock, D. Langworthy, H. Schran, and S. Sutton, Department of Microbiology, Miami University, for their laboratory and field assistance during the present study. We thank the Department of Zoology, Miami University, for sampling gear and especially M. Schaus for technical assistance throughout the study. The Department of Microbiology, Miami University, supported the present study. To the best of our knowledge, the experiments we conducted complied with state (Ohio) and federal (United States of America) regulations in force at that time.

\section{LITERATURE CITED}

Boenigk J (2004) A disintegration method for direct counting of bacteria in clay-dominated sediments: dissolving silicates and subsequent fluorescent staining of bacteria. J Microbiol Methods 56:151-159

Bowen SH (1979) Determinants of the chemical composition 
of periphytic detrital aggregate in a tropical lake (Lake Valencia, Venezuela). Arch Hydrobiol 87:166-177

Bowen SH (1984) Evidence of a detritus food chain based on consumption of organic precipitates. Bull Mar Sci 35: $440-448$

Bowen SH, Bonetto AA, Ahlgren MO (1984) Microorganisms and detritus in the diet of a typical neotropical riverine detritivore, Prochilodus platensis (Pisces: Prochilodontidae). Limnol Oceanogr 29:1120-1122

Bowen SH, Gu B, Huang Z (2006) Diet and digestion in Chinese mud carp Cirrhinus molitorella compared with other ilyophagous fishes. Trans Am Fish Soc 135:1383-1388

Cammen LM (1991) Annual bacterial production in relation to benthic microalgal production and sediment oxygen uptake in an intertidal sandflat and intertidal mudflat. Mar Ecol Prog Ser 71:13-25

Cebrian J (2004) Role of first-order consumers in ecosystem carbon flow. Ecol Lett 7:232-240

Cebrian J, Lartigue J (2004) Patterns of herbivory and decomposition in aquatic and terrestrial ecosystems. Ecol Monogr 74:237-259

Cummins KW (1974) Structure and function of stream ecosystems. Bioscience 24:631-641

Diamond J (1991) Evolutionary design of intestinal nutrient absorption: enough but not too much. News Physiol Sci 6: 92-96

Dobbs FC, Findlay RH (1993) Analysis of microbial lipids to determine biomass and detect the response of sedimentary microorganism to disturbance. In: Kemp PF, Sherr BF, Sherr EB, Cole JJ (eds) Handbook of methods in aquatic microbial ecology. Lewis Publishers, Boca Raton, FL

$>$ Dobbs FC, Guckert JB (1988) Microbial food resources of the macrofaunal-deposit feeder Ptychodera bahamensis (Hemichordata: Enteropneusta). Mar Ecol Prog Ser 45:127-136

Findlay RH (2004) Determination of microbial community structure using phospholipid fatty acid profiles. In: Kowalchuk GA, de Bruijn FJ, Head IM, Akkermans ADL, Van Elsas JD (eds) Molecular microbial ecology manual, 2nd edn. Kluwer Academic Publishers, Dordrecht

Findlay RH, Dobbs FC (1993) Quantitative description of microbial communities using lipid analysis. In: Kemp PF, Sherr BF, Sherr EB, Cole JJ (eds) Handbook of methods in aquatic microbial ecology. Lewis Publishers, Boca Raton, FL

Findlay RH, White DC (1983) The effects of feeding by the sand dollar Mellita quinquiesperforata on the benthic microbial community. J Exp Mar Biol Ecol 72:25-41

> Findlay RH, King GM, Watling L (1989) Efficacy of phospholipid analysis in determining microbial biomass in sediments. Appl Environ Microbiol 55:2888-2893

Findlay RH, Trexler MB, White DC (1990) Response of a benthic microbial community to biotic disturbance. Mar Ecol Prog Ser 62:135-148

Garvey JE, Dingledine NA, Donovan NS, Stein RA (1998) Exploring spatial and temporal variation within reservoir food webs: predictions for fish assemblages. Ecol Appl 8: $104-120$

Gido KB (2003) Effects of gizzard shad on benthic communities in reservoirs. J Fish Biol 62:1392-1404

Gough HL, Stahl DA (2003) Optimization of direct cell counting in sediment. J Microbiol Methods 52:39-46

> Gu B, Schelske CL, Hoyer MV (1996) Stable isotopes of carbon and nitrogen as indicators of diet and trophic structure of the fish community in a shallow hypereutrophic lake. J Fish Biol 49:1233-1243

> Hairston Jr NG, Hairston Sr NG (1993) Cause-effect relationships in energy flow, trophic structure, and interspecific interactions. Am Nat 142:379-411

Hall RO, Meyer JL (1998) The trophic significance of bacteria in a detritus-based stream food web. Ecology 79:1995-2012

> Higgins KA, Vanni MJ, Gonzalez MJ (2006) Detritivory and the stoichiometry of nutrient cycling by a dominant fish species in lakes of varying productivity. Oikos 114:419-430

Kim GW, Wintzer AP, Menker TK, Stein RA, Dettmers JM, Wright RA, DeVries DR (2007) Effect of detritus quality on growth and survival of gizzard shad (Dorosoma cepedianum): potential importance to benthic-pelagic coupling. Can J Fish Aquat Sci 64:1805-1815

> Lopez GP, Levinton JS (1987) Ecology of deposit-feeding animals in marine sediments. Q Rev Biol 62:235-260

> MacGinitie GE (1932) The role of bacteria as food for bottom animals. Science 76:490

> Mayer LM, Jumars PA, Taghon GL, Macko SA, Trumbore S (1993) Low-density particles as potential nitrogenous food sources for benthos. J Mar Res 51:373-389

Mayer LM, Schick LL, Sawyer T, Plante CJ, Jumars PA, Self RL (1995) Bioavailable amino acids in sediments: a biomimetic, kinetics-based approach. Limnol Oceanogr 40: $511-520$

> Mayer LM, Schick LL, Self RFL, Jumars PA, Findlay RH, Chen Z, Sampson S (1997) Digestive environments of benthic macroinvertebrate guts: enzymes, surfactants and dissolved organic matter. J Mar Res 55:785-812

Moore JC, Berlow EL, Coleman DC, de Ruiter PC and others (2004) Detritus, trophic dynamics and biodiversity. Ecol Lett 7:584-600

Moriarty DJW (1973) The physiology of digestion of blue-green algae in the cichlid fish, Tilapia nilotica. J Zool 171:25-39

Mundahl ND (1984) Growth and condition of gizzard shad (Dorsoma cepedianum) in Acton Lake, Ohio: relationships to food quality. PhD dissertation, Miami University, Oxford, $\mathrm{OH}$

> Mundahl ND (1991) Sediment processing by gizzard shad, Dorosoma cedianum (Lesueur), in Acton Lake, Ohio, USA J Fish Biol 38:565-572

Neidhardt FC, Ingraham JL, Schaechter M (1990) Physiology of the bacterial cell: a molecular approach. Sinauer Associates, Sunderland, MA

Nowlin WH, Evarts JL, Vanni MJ (2005) Release rates and potential fates of nitrogen and phosphorus from sediments in a eutrophic reservoir. Freshw Biol 50:301-322

Pace ML, Cole JJ, Carpenter SR, Kitchell JF and others (2004) Whole-lake carbon-13 additions reveal terrestrial support of aquatic food webs. Nature 427:240-243

> Penry DL, Jumars PA (1986) Chemical reactor analysis and optimal digestion. Bioscience 36:310-315

$>$ Penry DL, Jumars PA (1987) Modeling animal guts as chemical reactors. Am Nat 129:69-96

Pierce RJ (1977) Life history and ecological energetics of the gizzard shad (Dorosoma cepedianum) in Acton Lake, Ohio. PhD dissertation, Miami University, Oxford, $\mathrm{OH}$

> Pierce RJ, Wissing TE, Jaworski JG, Givens RN, Megrey BA (1980) Energy storage and utilization patterns of gizzard shad in Acton Lake, Ohio. Trans Am Fish Soc 109:611-616

Pierce RJ, Wissing TE, Megrey BA (1981) Aspects of the feeding ecology of gizzard shad in Acton Lake, Ohio. Trans Am Fish Soc 110:391-395

> Plante CJ, Mayer LM (1994) Distribution and efficiency of bacteriolysis in the gut of Arenicula marina and three additional deposit feeders. Mar Ecol Prog Ser 109:183-194

> Salvatore SR, Mundahl ND, Wissing TE (1987) Effect of water temperature on food evacuation rate and feeding activity of age-0 gizzard shad. Trans Am Fish Soc 116:67-70

Sanderson SL, Cheer AY, Goodrich JS, Graziano JD, Callan 
WT (2001) Crossflow filtration in suspension-feeding fishes. Nature 412:439-441

Schaus MH, Vanni MJ, Wissing TE, Bremigan MT, Garvey JE, Stein RA (1997) Nitrogen and phosphorus excretion by detritivorous gizzard shad in a reservoir ecosystem. Limnol Oceanogr 42:1386-1397

Schaus MH, Vanni MJ, Wissing TE (2002) Biomass-dependant diet shifts in omnivorous gizzard shad: implications for growth, food web, and ecosystem effects. Trans Am Fish Soc 131:40-54

Smoot JC, Findlay RH (2000) Digestive enzyme and gut surfactant activity of detritivorous gizzard shad. Can J Fish Aquat Sci 57:1113-1119

Smoot JC, Findlay RH (2001) Spatial and seasonal variation in a reservoir sedimentary microbial community as determined by phospholipid analysis. Microb Ecol 42:350-358

Smoot JC, Findlay RH (2010) Density fractionation of freshwater sediments to assess the potential of microorganisms as a food source for sediment-ingesting detritivores. Aquat Microb Ecol (in press) doi:10.3354/ame01383

Stein RA, DeVries DR, Dettmers JM (1995) Food web regulation by a planktivore: exploring the generality of the trophic cascade hypothesis. Can J Fish Aquat Sci 52: $2518-2526$

> Vadeboncoeur Y, Vander Zanden MJ, Lodge DM (2002) Putting the lake back together: reintegrating benthic pathways into lake food web models. Bioscience 52:44-54

van Oevelen D, Moodley L, Soetaert K, Middelburg JJ (2006) The trophic significance of bacterial carbon in a marine intertidal sediment: results of an in situ stable isotope labeling study. Limnol Oceanogr 51:2349-2359

Vander Zanden MJ, Vadeboncoeur Y (2002) Fishes as integrators of benthic and pelagic food webs. Ecology 83:

Editorial responsibility: Anne Hershey,

Greensboro, North Carolina, USA
$2152-2161$

- Vanni MJ (2002) Nutrient cycling by animals in freshwater ecosystems. Annu Rev Ecol Syst 33:341-370

Vanni MJ, Headworth JL (2004) Cross-habitat transport of nutrients by omnivorous fish along a productivity gradient: integrating watersheds and reservoir food webs. In: Polis GA, Power ME, Huxel GL (eds) Food webs at the landscape level. University of Chicago Press, Chicago, IL, p 43-61

Vanni MJ, Arend KK, Bremigan MT, Bunnell DB and others (2005) Linking landscapes and food webs: effects of omnivorous fish and watersheds on reservoir ecosystems. Bioscience 55:155-167

Vestal JR, White DC (1989) Lipid analysis in microbial ecology quantitative approaches to the study of microbial communities. Bioscience 39:535-541

Volesky B, Zajic JE, Knetting E (1969) Algal products. In: Zajic JE (ed) Properties and products of algae; proceedings. Plenum Press, New York, p 49-62

Weir HC, Churchill EP (1945) The anatomy and histology of the digestive system of the gizzard shad. Proc Acad Sci 25: $34-43$

White DC, Pinkart HC, Ringelberg DB (1997) Biomass measurements: biochemical approaches. In: Hurst CJ, Knudsen GR, McInerney MJ, Stetzenbach LD, Walter MV (eds) Manual of environmental microbiology. ASM Press, Washington, DC, p 91-101

Whitman WB, Coleman DC, Wiebe WJ (1998) Prokaryotes: the unseen majority. Proc Natl Acad Sci USA 95: $6578-6583$

Wright RR, Hobbie JE (1966) Use of glucose and acetate by bacteria and algae in aquatic ecosystems. Ecology 47: $447-464$

Submitted: April 30, 2009; Accepted: October 13, 2009

Proofs received from author(s): December 24, 2009 